\title{
土石流の合流角度が 本川合流点の堆積に及ぼす影響 EFFECT OF DEBRIS FLOW CONFLUENCE ON MAIN CHANNLE DEPOSITION CONSIDERING JUNCTION ANGLE
}

\author{
中谷加奈 1 ・坂田拓朗 $2 \cdot$ 前田大介 3 ・里深好文 4 ・水山高久 5 \\ Kana NAKATANI ${ }^{1}$, Takuro SAKATA ${ }^{2}$, Daisuke MAEDA ${ }^{3}$,Yoshifumi SATOFUKA ${ }^{4}$ \\ and Takahisa MIZUYAMA ${ }^{5}$
}

\author{
1正会員 博 (農) 京都大学助教 農学研究科森林科学専攻（广606-8502 京都市左京区北白川追分町） \\ 2非会員 京都大学農学部森林科学科（干606-8502 京都市左京区北白川追分町） \\ 3非会員 農修 ヤフー株式会社（テ107-6211東京都港区赤坂9-7-1） \\ 4正会員 博(工） 立命館大学教授 理工学部都市システム工学科（テ525-8577 滋賀県草津市野路東 \\ 1-1-1) \\ 5正会員 農博 京都大学教授 農学研究科森林科学専攻（二606-8502 京都市左京区北白川追分町）
}

When a large-scale rain event occurs, a small-scale bank collapse and sediment transportation may be caused at the junction of mountain streams. This may result in debris flow that continues downstream to join the main channel. The effect of a mountain tributary on the main river is usually negligible because its discharge volume is small compared to the main river. However, when debris flow occurs, the impact of the tributary on the main river is significant because the discharge becomes large compared to the normal situation. The difference between the discharge volumes of the tributary and the main stream, the slope angle, and the confluence junction angle all seem to have an effect. In this study, we considered the junction angle of the debris flow at the confluence of two channels. We first examined previous studies and past events of debris flow confluence to analyze the trends and to determine the average junction angle. We then conducted debris flow experiments with different channel junction angles.

Key Words : Debris flow, confluence, deposition, junction angle, case classification, channel experiments

\section{1. はじめに}

山地河川では，大きな降雨イベントが発生した際に， 崩壊や小規模河道閉塞の決壊, 渓床堆積物の移動などが, 複数の渓流から発生することがある. 発生した土砂は, 土石流や土砂流として流下し，本川に合流する場合が多 い. 実際の土石流災害でも, 複数の支川から土砂が本川 に流入したと考えられるケースが少なくない，例えば, 図-1の様に2009年7月山口県防府市八幡谷渓流で発生し た土石流1),2)などが挙げられる.

通常，支川における流量は少なく，本川に及ぼす影響 は小さい. しかし, 土石流や土砂流が発生すると, 平時 と比較して大量の土砂や水が流入することで, 本川に大 きな影響を与える．本川と支川における流量ピークや， 土砂流出のタイミングの違い, 本支川の勾配の違いなど
が影響すると考えられる．また，本支川の合流角度に よって, 平行に近いスムーズな合流と, 角度が付いて本 川と支川の流れ方向が異なるような合流では，流速や水 面挙動, 堆積過程が変化すると考えられる.

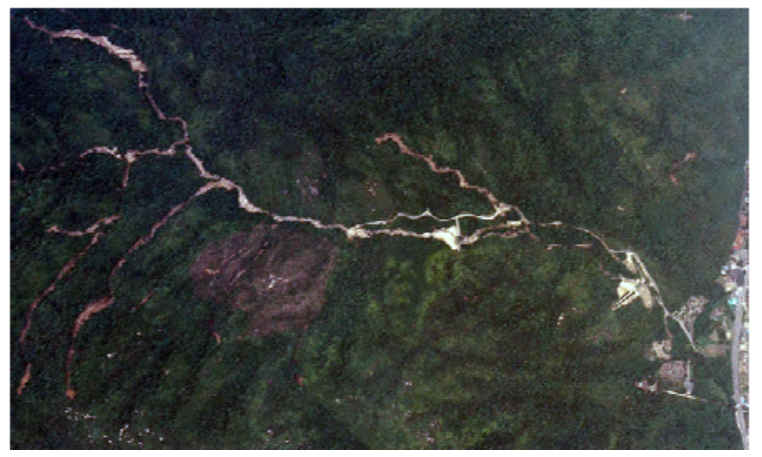

図-1２009年7月山口県防府市八幡谷で発生した複数の渓流 からの土砂移動（アジア航測株式会社より提供） 
本研究では，特に本川と支川の合流角度に着目して, 既往の土石流発生時の合流角度の検討，並びに水路実験 によって異なる合流角度の場合の支川合流部の流動・堆 積過程のデータを取得し，検証を行った。

\section{2. 合流角度の選定}

\section{（1）海外の合流研究}

海外の地形分野の研究で，合流角度の違いによって土 石流の合流部の挙動が変化する傾向を示した研究は複数 存在する゙ケ-6).

例えば，Benda\&(Cundy ${ }^{3}$ やMiller\&Burnett ${ }^{4}$ は，アメリ カのオレゴン州の事例を対象としており，70。を越えた 合流角度ではほとんどが合流部で堆積し，合流角度は大 きいほどより堆積しやすいと報告している.

Millard ${ }^{5} や G u t h r i e ら^{6}$ はカナダのブリティッシュコロン ビア州を対象としている，資料5では，崩土が渓流に流 入した際，土石流化して流動した場合と合流部で堆積し た場合を検討している. 土石流化した事例の平均合流角 度は，源頭からの崩土については $0^{\circ}$, 源頭より谷次数の 大きい谷からの崩土では平均74。で，どちらについても 堆積した場合と比べて流動化した場合の合流角度は小さ かった。 また，合流角度の影響は他の勾配などの地形条 件の影響に比べると小さいことも報告されている. 資料 6)では，合流部で堆積した事例の平均合流角度は70で, 合流部からもそのまま流動した事例の平均合流角度は 26ㄷ報告されている．また，合流部で堆積した事例の $75 \%$ 以上は合流角度が $45^{\circ}$ よりも大きく, 合流部からも

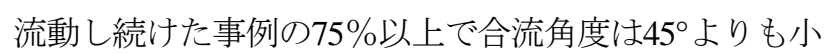
さいと報告されている.

\section{(2) 日本の合流研究}

\section{a) 既往研究}

日本では，緩勾配（常流）の河川に関しては，合流に ついての研究7,8)が既に行われている. しかし，急勾配 (射流)の山地河川での研究はあまり見られない，災害 報告や現地データの報告・紹介において「支川からの土 石流の発生が本川で河道を閉塞させて被害をもたらす」 等の記述を見ることはあるが9), 具体的な河床変動を記 録したデータはほとんど無い.

\section{b）日本で土石流が発生した事例での合流角度}

日本の既往研究や報告で，合流角度だけを対象として 集められたデー夕は存在しない，そこで，実際に発生し た土砂災害事例に関する4つの資料 ${ }^{10)-13)}$ を元に，一般的 と考えられる土石流の合流角度を検討した.

資料苂で石川は，既往の地震による土石流発生事例お よび非発生事例を収集・整理しており，地震による斜面 崩壊が土石流化する地形・地質条件を分析・検討してい る. 計測結果をまとめたデータから, 崩土が土石流化し
て渓流に流入したとされている8箇所を土石流の合流事 例と判断して本検討で用いた. この流入角の值を平均寸 ると $31.9^{\circ}$ となった。

資料 ${ }^{11)}$ で山田らは，複合型土石流の発生に関与寸る地 形要因を整理して, 統計的解析で各種の要因の重みを検 討している.ここで述べる複合型土石流とは，流出土砂 量が数万 $\mathrm{m}^{3}$ 〜数 10 万 $\mathrm{m}^{3}$ と比較的大きく, 崩土が河道に 流入した後も運動を継続して土石流化する特徵を持つ.

また, 崩土の運動が何らかの要因でその大部分が斜面下 部の河道付近に堆積した場合は, 天然ダムまたは崖錐が 形成されて複合型土石流は発生しない.

整理された地形データから, 崩土の河道への流入角度 が本研究で扱う合流角度と判断して, 検討に用いた. 複 合型土石流の発生した7事例の崩土の流入角度の平均は 31.4゚であった. なお，天然ダムが発生した6事例の平均 は84.20である. これは, 海外の事例と同様に, 合流角度 が大きい場合は, 合流部で堆積しやすく流動化しにくい 傾向を示している.

資料 ${ }^{12}$ からは，2009年に山口県防府市で大きな土砂移 動のあった渓流の中から, 複数の渓流からの土砂移動が みられた八幡谷, 剣川, 上田南, 奈美地区について, 航 空写真から合流角度を判読した結果（表-1），その平均 は47.9゚となった。

\section{表-1 山口県防府市での航空写真から判読した合流角度.}

\begin{tabular}{|c|c|}
\hline 地名 & 合流角度 $\left(^{\circ}\right)$ \\
\hline \hline 八幡谷 & 44 \\
& 42 \\
\hline 剣川 & 44 \\
& 40 \\
& 55 \\
\hline 上田南 & 45 \\
& 22 \\
& 55 \\
\hline 奈美 & 35 \\
& 75 \\
& 70 \\
\hline \hline 平均 & 47.9 \\
\hline
\end{tabular}

土砂移動の起こった河川の合流点の状況・写真を載せ た資料 ${ }^{13}$ から急勾配の山地河川を抽出して，合流角度を 平均すると72.30となった（表-2）。本資料には合流角度 だけでなく本・支川の勾配や川幅についても詳細に示さ れている.これより，本川は土砂流から掃流区間である こと，支川は土石流功土砂流区間であること，本川と

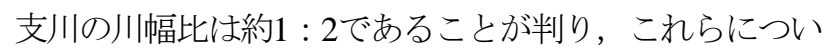
ても実験条件の参考とした.

この $4 つ の$ 資料での合流角度を平均すると $45.3^{\circ}$ となった

（表-3）。これより，平均的な合流角度は $45^{\circ}$ と示され た．また，概ね $230^{\circ}$ から $70^{\circ} の$ 範囲内に収まることも推定 された. 
表-2 資料 ${ }^{13)}$ の急勾配の山地河川の合流事例の本支川の 勾配 (合流点直上200m地点)，川幅，合流角度 (- : データ無).

\begin{tabular}{|c|c|c|c|c|c|}
\hline 河川名 & $\begin{array}{l}\text { 本川 } \\
\text { 勾配 } \\
\left({ }^{\circ}\right)\end{array}$ & $\begin{array}{l}\text { 支川 } \\
\text { 勾配 } \\
\left({ }^{\circ}\right)\end{array}$ & $\begin{array}{c}\text { 本川 } \\
\text { 川幅 } \\
(\mathrm{m})\end{array}$ & $\begin{array}{l}\text { 支川 } \\
\text { 川幅 } \\
\text { (m) }\end{array}$ & $\begin{array}{c}\text { 合流 } \\
\text { 角度 } \\
\left({ }^{\circ}\right)\end{array}$ \\
\hline 最上川 & 1.4 & 11.3 & 150 & 5 & 90 \\
\hline 利根川 & 6.1 & 12.3 & 50 & 30 & 50 \\
\hline 利根川 & 3.6 & 16.4 & 40 & 30 & 90 \\
\hline 利根川 & 3.4 & 7.9 & 100 & 30 & 45 \\
\hline 富士川 & 0.8 & 17.9 & 100 & 10 & 90 \\
\hline 富士川 & 1.1 & 10.3 & 50 & 220 & 120 \\
\hline 信濃川 & 3.5 & 4.5 & 20 & 80 & 60 \\
\hline 信濃川 & 1.4 & 4.6 & 50 & 65 & 80 \\
\hline 手取川 & 1.8 & 13.1 & 40 & 20 & 50 \\
\hline 神通川 & 2.1 & 5.1 & 105 & 25 & 75 \\
\hline 神通川 & 2.2 & 6.3 & 110 & 25 & 89 \\
\hline 天竜川 & 4.1 & 21.8 & 100 & - & 90 \\
\hline 木曽川 & 0.6 & 4.8 & 70 & 70 & 90 \\
\hline 安倍川 & 2.3 & 4.8 & 40 & 30 & 85 \\
\hline 安倍川 & 1.2 & 3.8 & 120 & 6 & 35 \\
\hline 安倍川 & 5.7 & 5.2 & 40 & - & 25 \\
\hline 吉野川 & 0.4 & 11.3 & 40 & 10 & 90 \\
\hline 重信川 & 2.7 & 11.3 & 20 & 3 & 90 \\
\hline 球磨川 & $\begin{array}{l}4.8 \\
\end{array}$ & 14.7 & 25 & 5 & 40 \\
\hline 球磨川 & 2.7 & 11.8 & 100 & 10 & 40 \\
\hline 球磨川 & 1.8 & 10.7 & 50 & 10 & 90 \\
\hline 球磨川 & 7.5 & 8.9 & 15 & 10 & 40 \\
\hline 球磨川 & 7.6 & 9.5 & 25 & 10 & 120 \\
\hline 桜島 & 10.7 & 15.5 & 130 & 17 & 60 \\
\hline 平均 & $\begin{array}{l}3.32 \\
\end{array}$ & $\begin{array}{l}10.2 \\
\end{array}$ & 666.25 & 30.04 & $\begin{array}{ll}72.3 \\
\end{array}$ \\
\hline
\end{tabular}

表-3 参考資料 ${ }^{10)-13)}$ から求めた合流角度.

\begin{tabular}{|c|c|}
\hline 参考資料 & 平均の合流角度 $\left(^{\circ}\right)$ \\
\hline \hline 10$)$ 石川芳治 (1999) & 31.9 \\
\hline 11) 山田孝他 (2000) & 31.4 \\
\cline { 2 - 3 } & $\begin{array}{c}\text { (天然ダム発生 } \\
\text { 事例84.2) }\end{array}$ \\
\hline $\begin{array}{c}\text { 12) 砂防・地すべり技術セ } \\
\text { ンター(2010) }\end{array}$ & 47.9 \\
\hline $\begin{array}{c}\text { 13) 建設省士木研究所砂防部 } \\
\text { 砂方研究室(1989) }\end{array}$ & 72.3 \\
\hline \hline $\begin{array}{c}\text { 資料10) -13) の平均 } \\
(\text { 但し, 11)の天然ダム発生 } \\
\text { 事例は除く) }\end{array}$ & 45.3 \\
\hline
\end{tabular}

そこで，次章で実施する実験水路の支川と本川との合 流角度を $45^{\circ}$ と決定した。 また，資料 ${ }^{9}$ や海外の合流研究 事例 ${ }^{3)-6)}$ からも示されたように，天然ダムが形成される 場合には90近くで合流する事例も少なくない，運動量 損失等を考慮すると, 90 合流は最も極端なケースと考 えられるため，90の実験も行った．更に，実際の災害 事例で見られて，この中間である60も実験を行った.
資料 ${ }^{13)}$ を参考に，本川勾配は掃流区間として5，支川 勾配は土石流領域として15，本川と支川の川幅比は約 $2: 1$ とした.

\section{3. 水路実験}

\section{（1）実験手順}

支川水路で発生した土石流が本川水路に合流する際の 挙動を，ハイスピードカメラ (300fps) で撮影し，水深 と河床変化を計測した.

大小2基の直線水路をそれぞれ本川水路，支川水路と した．本川水路は，水路長 $4 \mathrm{~m}$, 水路幅 $15.5 \mathrm{~cm}$ ，河床勾 配5。であり，支川水路は水路長 $0.9 \mathrm{~m} ，$ 水路幅 $7.0 \mathrm{~cm}$ ，河 床勾配 $15^{\circ}$ である. 本川水路の下流端から $1 \mathrm{~m}$ の部分に支 川水路を接続した. 両方の水路には5 mm角の栈粗度を設 置した. 本川水路には $5 \mathrm{~cm}$ 間隔で，支川水路には $3 \mathrm{~cm}$ 間 隔で設置した.

図-2, 図-3に合流角度 $45^{\circ}$ の概要を示す。八イスピー ドカメラを用いて図-3に示した計測点A（合流点，本川 下流端から $1.0 \mathrm{~m}$ 上流，合流部ジョイントの下流側），並 びに計測点B（Aから0.4 m下流）での水位・堆積厚を計 測した。 なお，横断方向に水位，堆積厚は異なっており， その違いは合流点の堆積厚において顕著だが，以下に示 すデータは右岸から撮影, 計測しているため, 最大值を 示している.

予め支川水路に土砂を厚さ $5 \mathrm{~cm}$ に敷き詰めて，本川・ 支川の上流端から水の久をポンプで一定流量供給する手 法を取った. 使用した砂はほぼ一様で平均粒径は2.9mm, 砂碩密度は $2.59 \mathrm{~g} / \mathrm{cm}^{3}$, 土砂の総量は空隙を含めて3.15L である. 以下に実験手順を示す。

(1)支川水路に土砂を敷き詰める. (厚さ $5 \mathrm{~cm}$ )

(2)本川に一定流量で予水を供給しておく.

(3)支川に一定流量で水を供給し，土石流を発生させる. (この時点を実験開始とする)

(4)支川の給水開始加ら 25 秒後に，支川の水を止める.

(5)支川の給水開始加ら60秒後に，本川の水を止める.

表-4に示寸流量（水のみ）を本川水路, 支川水路の上 流端から供給した.

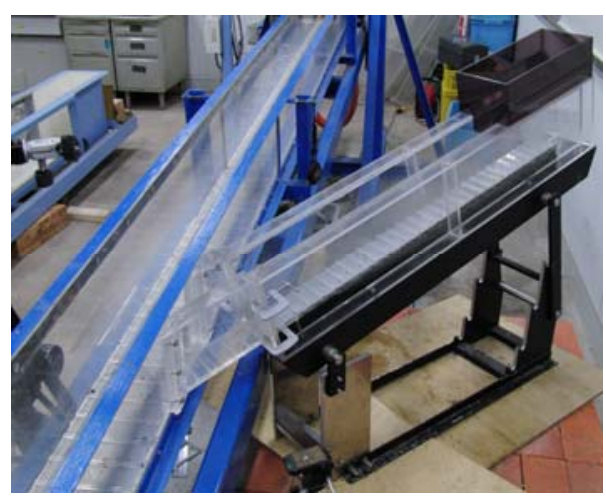

図-2＼cjkstart模型水路（合流角度 $45^{\circ} ）$ 


\section{本川水路}

水路幅： $15.5 \mathrm{~cm} 、$ 勾配 : $5^{\circ}$

支川水路

水路幅： $7 \mathrm{~cm} 、$ 勾配 : $15^{\circ}$

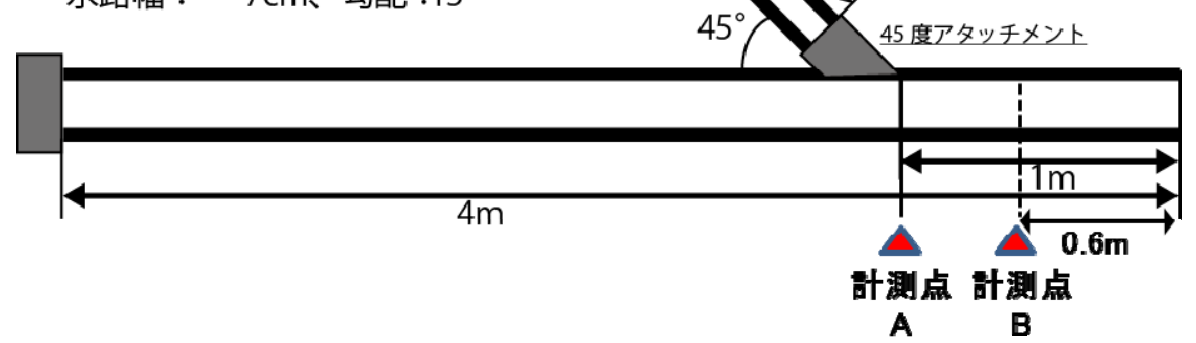

図-3 模型水路概要（合流角度 $45^{\circ} ）$.

表-4 実験ケース.

\begin{tabular}{|c|c|c|}
\hline & 支川流量(L/sec) & 本川流量 $(\mathrm{L} / \mathrm{sec})$ \\
\hline \hline \multirow{2}{*}{ Case1 } & \multirow{3}{*}{0.3} & 0.3 \\
Case2 & & 0.5 \\
Case3 & \multirow{2}{*}{0.5} & 0.7 \\
Case4 & & 1.0 \\
\cline { 3 - 3 } & & \\
\cline { 3 - 3 } & &
\end{tabular}

\section{（2）実験結果}

支川流量が0.3L/sのCase1〜Case4までの合流点（計測 点A）での水位変化を図-4～図-6, 合流点から $40 \mathrm{~cm}$ 下流 (計測点 $B$ ) での水位変化を図-7〜図-9に，合流点（計 測点A）での堆積厚変化を図-10～図-12に示す，それぞ れの図中の凡例は，本川の流量を示寸.

なお，合流点から $40 \mathrm{~cm}$ 下流（計測点 $\mathrm{B}$ ) での堆積厚変 化は，ほとんどの本川流量・合流角度のケースで掃流状 態であり大きな違いが時系列的に認められなかったため, 本稿には記載していない.

\section{a）合流点での水位変化}

図-4〜図-6より合流点（計測点A）での水位変化は, 支川から土石流が合流する前は，本川流量が大きいほど 水位が大きい. 合流点では, 土石流が合流した後, 支川 からの土石流によって水位が上昇するが，上昇した水位 については本川流量による水位の違いはみられず，ほぼ 同じ值となった．また，合流角度による違いもあまり見 られなかった．これは，合流点においては支川からの土 石流の影響が大きいためと考えられる.

b) 合流点から $40 \mathrm{~cm}$ 下流での水位変化

図-7〜図-9から，合流点から $40 \mathrm{~cm}$ 下流（計測点B）の 水位変化も, 支川から土石流が合流寸る前は, 本川流量 が大きいほど水位が大きい.

また，土石流が合流した影響による水位変化は，全て の合流角度について, 本川流量が大きいほど小さくなる。

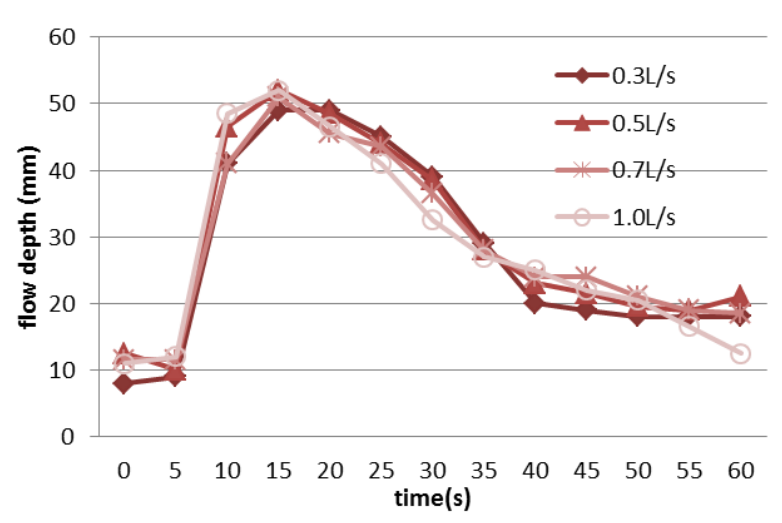

図-4 合流点（計測点 $\mathrm{A} ）$ の水位変化（合流角度 $45^{\circ} ）$ 。

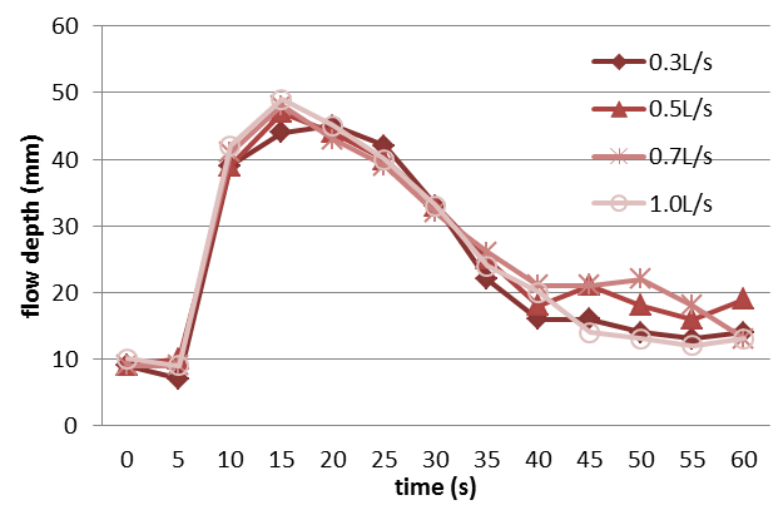

図-5 合流点（計測点 $A ）$ の水位変化（合流角度 $60^{\circ} ）$.

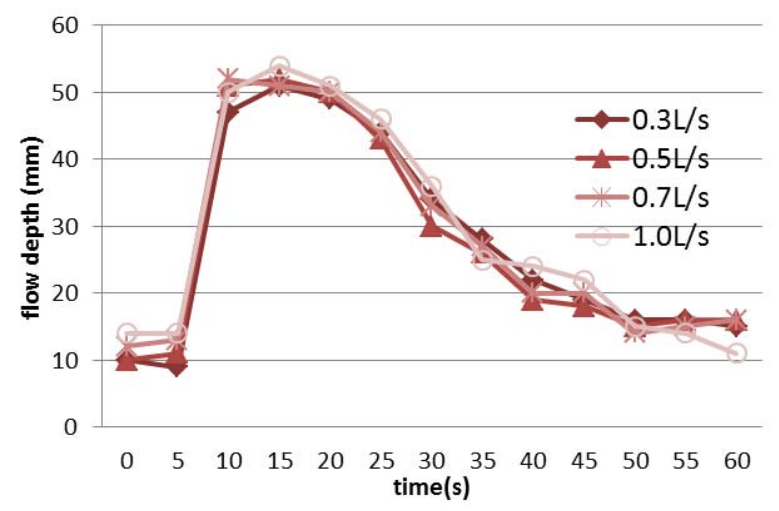

図-6 合流点（計測点 $\mathrm{A} ）$ の水位変化（合流角度 $90^{\circ} ）$ 。 
土石流合流後の水位上昇は，上流の合流点と比べて小さ く，支川の土石流の影響が比較的小さいと推測される.

また，合流角度によって異なる傾向がみられた，合流 角度が $45^{\circ}$ では，土石流合流後も本川流量が大きいほど 水位が大きい傾向が維持されている（図-7）。合流角度 $60^{\circ}$ では，本川流量が $0.3 \mathrm{~L} / \mathrm{s}$ と小さい場合に土石流が合流 した後に水位が急激に上昇して，本川流量が $1.0 \mathrm{~L} / \mathrm{s} の$ ケースよりも水位が大きい（図-8）。更に，合流角度 90॰では本川流量が小さい3ケースで，土石流が合流した 後に水位が急激に上昇して，本川流量が最大の $1.0 \mathrm{~L} / \mathrm{s} の$ ケースよりも水位が大きい，合流の影響で水位が最も大 きいのは0.5L/sで25mm, 次いで0.3L/sで24mm, 0.7L/sで $21 \mathrm{~mm}$ の順だが，合流前の水位と比較するとその差は $0.3 \mathrm{~L} / \mathrm{s}$ で $15 \mathrm{~mm}, 0.5 \mathrm{~L} / \mathrm{s}$ で $14 \mathrm{~mm}, 0.7 \mathrm{~L} / \mathrm{s}$ で $7 \mathrm{~mm}$ であり， $0.3 \mathrm{~L} / \mathrm{s}$ が最も大きい．また，水位が高い状態が継続する 時間も0.3L/s が50秒と最も長い。（図-9）。

これより，合流角度が小さいと支川からの土石流合流 が本川下流に及ぼす影響は少なく, 合流角度が大きいと その影響は大きいことが判る。合流角度が大きい場合， 本川流量が小さいほど合流前の状態と比較して水位上昇 が大きく，水位が大きい状態の継続時間が長く，前者よ り危険側の条件となることが判る.

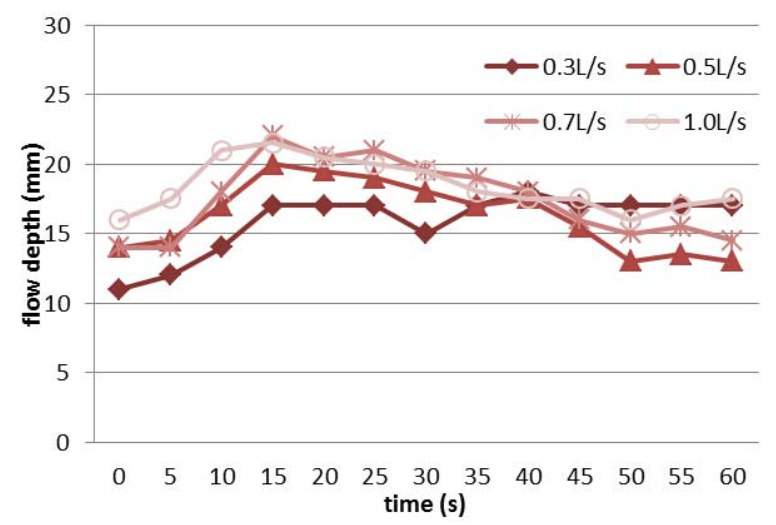

図-7 合流点から $40 \mathrm{~cm}$ 下流（計測点B）の水位変化 （合流角度 $45^{\circ}$ )。

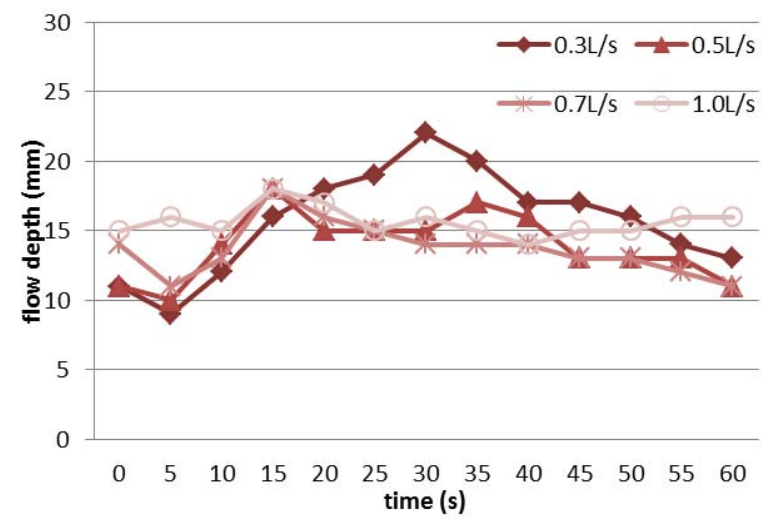

図-8 合流点から $40 \mathrm{~cm}$ 下流（計測点B）の水位変化 （合流角度 $60^{\circ}$ ）。 c) 合流点での堆積厚変化

図-10〜図-12より合流点（計測点A）での合流の影響 による堆積厚変化は，本川流量が小さい程大きく，合流 角度が大きい程変化が大きい，堆積は，通水開始5-10秒 で生じる．どの合流角度でも本川流量 $0.3 \mathrm{~L} / \mathrm{s}$ で堆積厚が 大きい. 90では全流量で顕著な堆積が生じて, 流量が 小さいと土砂は侵食されにくく, 堆積が長く継続する.

次に, 合流点の堆積厚変化と合流点下流（計測点B） の水位変化の対応を合流角度毎に考察する．45では， 合流点の土砂の堆積厚（図-10）は他の合流角度と比べ て小さく, 合流点下部の水位上昇も（図-7）概社 $5 \mathrm{~mm}$ と 小さい. $60^{\circ}$ では, $45^{\circ}$ と比較して合流点での堆積厚が大 きい（図-11）。本川流量0.3L/sでは10秒で約11mmと最 も厚く堆積し, 合流点下流の水位も（図-8）30秒で 22mmとなり最も大きい. $90^{\circ}$ では，合流点での堆積厚が 最大で，10秒で最大の堆積厚となる (図-12)。その後, 堆積厚が減少し始めると, 合流点下部の水位（図-9）が 最大となる.この傾向は, 本川流量が小さいほど顕著で ある. 本川流量 $0.3 \mathrm{~L} / \mathrm{s}$ では，合流点で10秒時点で最大 32 mm堆積した後, 40秒で6 mmまで減少する. それに伴い, 合流部下流の水位変化は10-15秒の間で約 $10 \mathrm{~mm}$ も急増し て，60秒まで比較的大きな水位を維持する. これは合流 部で一時的に堆積した土砂が, 本川の水で再侵食されて 流下して，下流側の水位が急上昇したと考えられる.

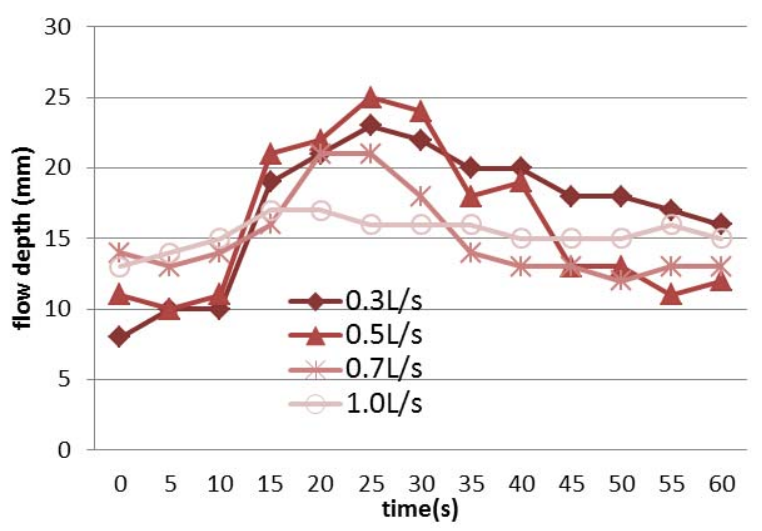

図-9 合流点から $40 \mathrm{~cm}$ 下流 (計測点B) の水位変化 （合流角度 $90^{\circ}$ ）。

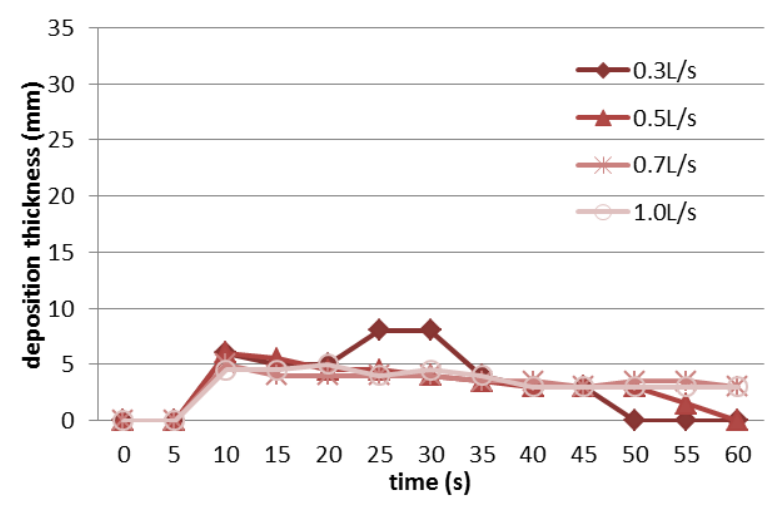

図-10 合流点（計測点A）の堆積厚変化（合流角度 $45^{\circ} ）$. 


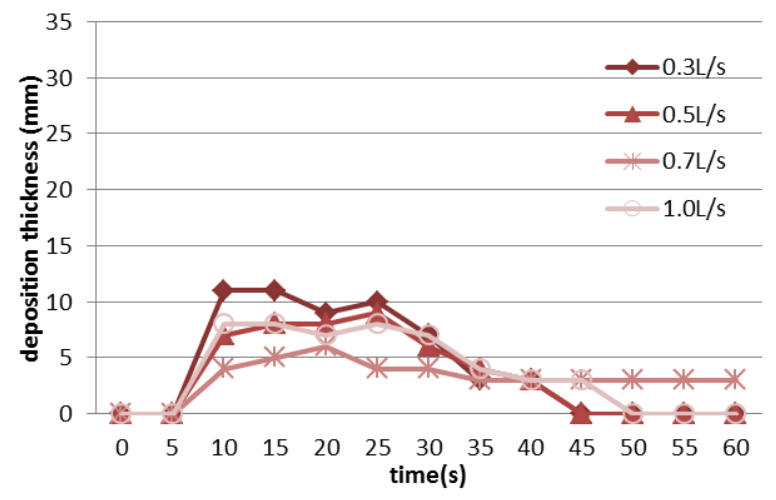

図-11 合流点（計測点 $\mathrm{A} ）$ の堆積厚変化（合流角度 $60^{\circ} ）$.

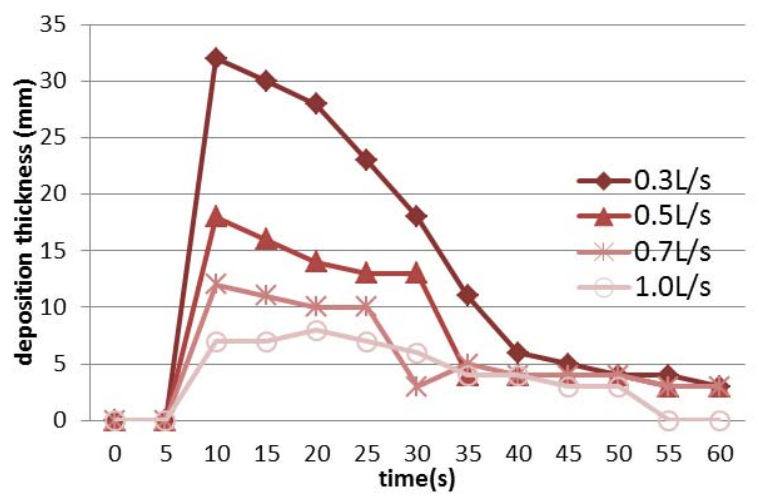

図-12 合流点（計測点A）の堆積厚变化（合流角度 $90^{\circ} ）$.

\section{4. おわりに}

本研究では，土石流が本川に合流する際の合流角度の 影響を検討した．海外の土石流合流事例からは，合流角 度は大きい方が合流部で堆積寸る場合が多く, 合流角度 が小さい場合の方が比較的合流部から下流にも流出する ことが判った. 次に，日本の合流事例を分類すると平均 は $45^{\circ}$ で, 概ね $230^{\circ} \sim 70^{\circ}$ の範囲内であることが判った.

選定した平均的な合流角度を元に，異なる合流角度に おける水位・堆積厚変化を水路実験で検討した. 合流角 度が小さい $45^{\circ}$ では, 合流点の堆積や合流点下流の水位 に土石流合流の影響はそれほどみられなかった．合流角 度の大きな $60^{\circ} や 90^{\circ}$ では，本川流量が小さいと合流点で 急激な土砂堆積を引き起こす，堆積した土砂が，本川か らの水で侵食されたときに，急激な水位上昇が合流点の 下流でみられた。特に $90^{\circ}$ では，合流点での顕著な土砂 堆積や，合流点下流での急激な水位上昇，大きな堆積厚 や水位状態が長く継続する現象がみられた．実災害でも， 平成23年和歌山県那智川金山谷川77の様に，土石流合流 が影響したと推定され，被害が大きい事例は，90に近 い大きな合流角度であり，実験結果と対応する.

このように，合流角度によって支川からの土石流合流 による本川の河床変動や水位上昇過程が変わることから, 今後の土砂災害や洪水災害への対策を検討寸る際，合流
角度を一つの指標として優先順位や対策規模を決定する ことは，より合理的であると考えらえる.

謝辞 : 本研究は, 平成23年度砂防・地すべり技術セン ター研究開発助成を受けて実施した.

\section{参考文献}

1) 古川浩平，海掘正博，久保田哲也，地頭哣隆，権田豊，杉原 成満，林真一郎，池田暁彦，荒木義則，柏原佳明：2009年 7 月21日山口県防府市での土砂災害緊急調查報告，砂防学会誌， Vol.62, No.3, pp.62-73, 2009.

2) 中谷加奈, 前田大介, 里深好文, 水山高久 : 平成21年7月に 山口県防府市石原地区及び八幡谷溪流で発生した土石流の検 討，第5回土砂災害に関するシンポジウム論文集，pp.81-86, 2010.

3) Benda, L.E., Cundy, T.W.: Predicting deposition of debris flows in mountain channels. Canadian Geotechnical Journal 27, pp.409-417, 1990.

4) Miller, D. J., Burnett, K.M.: A probabilistic model of debris-flow delivery to stream channels, demonstrated for the Coast Range of Oregon, USA, Geomorphology, Vol.94, pp.184-205, 2008.

5) Millard, T.H. :Debris flow initiation in coastal British Columbia gullies. Ministry of Forests, Nanaimo, BC. Technical Report, TR002. 1999.

6) Guthrie, R.H., Hockin, A., Colquhoun, L. , Nagy, T. , Evans, S.G., Ayles, C.: An examination of controls on debris flow mobility: Evidence from coastal British Columbia, Geomorphology, Vol.114, pp.601-613, 2010.

7) 松村和樹，藤田正治，山田孝，権田豊，沼本晋也，堤大三， 中谷加奈，今泉文寿，島田徹，海堀正博，鈴木浩二，徳永博， 柏原佳明，長野英次，横山修，鈴木拓郎，武澤永純，大野亮 一, 長山孝彦, 池島岡, 土屋智: 2011年台風12号による紀伊 半島で発生した土砂災害, 砂防学会誌, Vol.64, No.5, pp.4353, 2012.

8) 増田覚, 水山高久, 小田晃, 大槻英樹:本支川の出水のずれ による合流点の河床変動に関する研究，砂防学会誌，Vol.61, No.4, pp..27-31, 2008.

9) 出口恭, 藤田一郎, 椿涼太, 大薗政志: 勾配の異なる急勾配 河川合流部における固定床および移動床の解析，水工学論文 集第51巻, pp.823-828, 2007.

10)石川芳治：地震による土石流の発生に係わる地形，地質条 件, 砂防学会誌, Vol.51, No.5, pp.35-42, 1999.

11)山田孝, 南哲行, 菊池英明, 三浦郁人 : 複合型土石流の発 生に関与寸る地形要因についての統計的解析, 砂防学会誌, Vol.53, No.4, pp.23-29, 2000.

12)財団法人砂防・地すべり技術センター: 平成21年土砂災害 の実態, 2010.

13)合流点における土砂堆積状況写真集 : 平成元年3月, 建設省 土木研究所砂防部砂防研究室, 1989.

(2012. 9. 30受付) 